\title{
Women as Part of the Patriarchy: Masculinity, Women, and Relationships in Virginia Woolf's Novels
}

\author{
David Powers Corwin \\ George Mason University, Fairfax VA, USA
}

\begin{abstract}
This article focuses on three of Virginia Woolf's widely read novels, Jacob's Room, Mrs. Dalloway, and To the Lighthouse. I focus on the male protagonists in the novels Jacob Flanders, Richard Dalloway, and Mr. Ramsay. Up to this point, literary studies and women's studies almost focus on the positive female characters in her works and ignore the constructs of masculinity that she discusses in her fiction. Furthermore, critics do not critique the female characters and take into consideration their role as perpetrators in the patriarchy in order to maintain the patriarchal regime. I argue that the female characters in these novels police the male characters in their performance of masculinity, which in turn makes them perpetrators of the same discourse that in turn oppresses them. In this article, I use theorists such as Judith Butler, Nancy Chodorow, and Judith (who now identifies as Jack) Halberstam to discuss the sex/gender system and how women can hold oppressive roles within the patriarchy. Finally, I will conclude that Virginia Woolf needs more exposure with feminist theory and masculinity studies because of the radical characterizations of people she promotes in her fiction.
\end{abstract}

Keywords: masculinity, patriarchy, Woolf

\section{Introduction}

When reading Woolf, critics often look for positive female characters, which provide an accurate and often nuanced lens for reading her work. In feminist literature, Virginia Woolf is seen as a foremother in paving the way for women writers in the twentieth century. Women's studies scholars use Woolf as a historical figure and look at her radical views (at the time) of women in her era and her struggle to gain a voice for women. Even though these observations are valid points, critics often overlook her male characters in her works. This negligence raises the questions: What are men's roles in her fiction? What does Virginia Woolf say about masculinity? Woolf speaks to stereotypes of masculinity in her fiction—an area of feminist theory that is often overlooked within her works. Also, Woolf takes into consideration women's role as perpetrators within the patriarchy and examines this concept through dialogues between men and women in her works especially between love interests. Her novels Jacob's Room, Mrs. Dalloway, and To the Lighthouse especially focus on relationships that provide context for Woolf's depictions of masculinity.

In this article, I argue that Woolf's female characters perpetuate the ideological discourse of masculinity rather than only seeing women in positive lights. However, Woolf manifests these relationships through a variety of mediums. For example, the women's interactions with the male characters convey the discourse of hegemonic

David Powers Corwin, MAIS Women and Gender Studies/MA in English, George Mason University.

Correspondence concerning this article should be addressed to David Powers Corwin. 
masculinity. Also, Woolf satirizes the male characters' actions through narration and through other characters' perceptions of these characters. In the three novels mentioned above, Woolf uses the female protagonists as archetypes of women in her society because they police masculinity in a way that reinforces the gender binary that in turn oppresses these women. This article will focus on romantic relationships because gender binaries play a stronger role within these relationships than familial or other social relationships in the novels. I will use theorists, such as Judith Butler, Nancy Chodorow, and Judith Halberstam, as a means to discuss the sex/gender system and the relationship between masculinity and femininity in this novel.

\section{Jacob Flanders and Clara Durrant—Victorian Ideals of Gender}

In her novel, Jacob's Room, Woolf experiments with Modernist characteristics of characterization through her narrative construction. However, she also creates characters that reflect the social status of early 20th century British society. Jacob Flanders interacts with mostly female characters in his narrative and Woolf relies on these women's perceptions in order to create Jacob's character. With this information in mind, a close reading of the interactions with Jacob and these female characters is crucial to any analysis of masculinity in her works. Since Jacob encounters multiple women in his narrative, I am focusing on his relationship with Clara Durrant. Jacob's relationship with Clara shapes a large portion of his narrative and her interactions with him speak more to the social constructs of masculinity than the other female characters. Furthermore, Clara cleaves to the Victorian ideals of domesticity and marriage. Woolf writes that "Clara would hand the pretty china teacups, and smile at the compliment - that no one in London made tea so well” (Jacob's Room, p. 176). According to critic Rachel Hollander "Woolf seems to exclude women from these intimate and intensely connected encounters. Indeed, the heterosexual relationships portrayed in Jacob's Room, as many critics have pointed out, tend to relegate Jacob's lovers to traditionally subservient and stereotypical roles” (p. 59). Even though this statement applies to Jacob's relationships more broadly, Hollander's observation is definitely seen in Woolf's characterization of Clara. She fits the Victorian model of femininity and serves as an archetype of women in her society.

Clara embraces traditional gender roles and manifests these ideologies in her interactions with Jacob and her comments about him in his absence. For example, Jacob and Clara's conversation in the vineyard exemplifies Clara's rhetoric regarding gender roles. During this interaction, Clara does not allow Jacob to finish his thoughts. She insists that he come back to her home the next year and says, "you must come back next year, properly" (Jacob's Room, p. 62). When Jacob responds, he says, "If...If" and does not finish his statement (p. 63). Clara interprets their interaction as an ongoing relationship when in reality, Jacob comes to the Durrant's home in order to see Timothy, Clara's brother. In this case, her expectation of Jacob is to engage in this relationship which subtly illustrates the gender dichotomy in this narrative. Clara does not actively convey her ideas of gender; she conveys her need to be part of a monogamous relationship with a man.

Clara continues this discussion when Jacob leaves her after collecting his grapes. He says, "Oh Miss Durrant," but he never finishes his statement (Jacob's Room, p. 63). Woolf shifts to Clara's thoughts instead of allowing Clara to speak which deserves a close reading. Woolf relies mostly on the other character's perceptions of Jacob in order to create his narrative. Even in Clara's thoughts, she assigns gender roles to Jacob through her interactions. Woolf writes that Clara thinks, "You're too good—-too good" and "he [Jacob] must not say that he loves her” (p. 63). In Clara's mind, a relationship starts between them in which Jacob does not himself take part. She says that he must not express his feelings for her, but he does not have any feelings to express. Woolf's narrative technique satirizes this traditional thinking regarding Victorian ideals of marriage. In Clara's mind, a 
commitment should result from her interactions with men and expects the men she encounters to abide by social constructs of masculinity. In order to conduct a close analysis of gender norms, it is important to include some foundational theoretical texts regarding gender studies. Judith Butler is a leading scholar within feminist and queer theory. In Undoing Gender, Butler wishes to dismantle social constructs of gender. In her opinion, "a restrictive discourse on gender that insists on the binary of man and woman as the exclusive way to understand the gender field performs a regulatory operation of power that naturalizes the hegemonic instance and forecloses the think ability of its disruption” (Butler, p. 43). Clara illustrates this hegemonic discourse on gender because she refuses to deviate from gender binaries. Clara wishes to create the social ideal of marriage and superimposes this idea onto Jacob who shows no love interest in her. Woolf's technique conveys the discourse around masculinity in this piece which continues in Clara's thoughts about Jacob later in the narrative.

When Clara writes in her diary, she says, "I like Jacob Flanders...He is so unworldly. He gives himself no airs and one can say what one likes to him, though he's frightening because...” (Jacob's Room, p. 71). Woolf's characterization of Jacob through this unfinished diary deserves a close reading because it contributes to the discussion about perceptions of Jacob in the narrative; however, for this article, I will discuss Clara's decision not to continue writing on the next page and her rhetoric in her diary. Clara would not dare to differ from the norm and begin the next day's page which illustrates her need to abide by any structure that is set in place. Clara not only gives her opinion of Jacob, but she speaks to his personality in relation to the conversation they have in the vineyard. When she says that "one says what one likes to him", she does not take into consideration that Jacob says very little throughout their conversation (p. 71). She forces her ideas of their relationship upon Jacob and assumes that he is as engaged in the relationship as she is. Through her analysis of Jacob's personality, Clara assigns a role to Jacob that he never assigns to himself-the role as a romantic partner.

The narrator continues this discussion of masculinity and femininity after Clara finishes writing in her diary. Woolf writes that "It seems that men and women are equally at fault. It seems that a profound, impartial, and absolutely just opinion of our fellow-creatures is utterly unknown. Either we are men or we are women...Such is the manner of our seeing. Such the conditions of love” (pp. 72-73). This conclusion to Jacob and Clara's interactions suggests that gender plays a key role within their relationship. Clara sets the binary of men and women and manifests it in her definition of love. She creates a relationship between Jacob and her without fleshing out his feelings for her. Clara and Jacob never marry or even begin a courtship, which makes their relationship the most unique of, the other relationships discussed in this paper. The other two relationships are marriages between men and women and the expectations that wives have of their husbands. This attribute of their relationship illustrates how the legality of marriage is not what creates the binary that Butler describes that takes place in society, but it is a construct that is set up for any interaction between men and women. Furthermore, the discourse that Clara perpetuates insinuates that all interactions between men and women should lead to some type of romantic relationship, which commands reciprocation from her interactions with men. Clara's interactions with Jacob clearly illustrate how women have the capability of policing men's masculinity as a means of maintaining the patriarchal structure in society.

\section{Richard and Clarissa Dalloway-Who Should Buy the Flowers?}

Woolf's Mrs. Dalloway centers on the female protagonist Clarissa and her need to uphold society's definitions of what it means to be a woman. The novel begins with her planning of a party and the novel 
continues with this plotline. Woolf uses simultaneity of character's thoughts as they walk past each other in London as a means of defining her characters. Often, Mrs. Dalloway is read as a feminist text and Clarissa's character is analyzed under this critical lens. Critic Vereen Bell writes that Clarissa is often depicted as "the model of some human virtue - strength of character, intuitive genius, affirmation of life, transcendence of patriarchal social arrangements, empathy with the dead, unifier of society” (p. 94). Bell sees this analogy as a misreading of the novel and critiques this idea in her piece through use of particular scenes. Clarissa's femininity deserves a close reading in text; however, in order to analyze this text as a feminist piece, masculinity is in need of exploration as well.

In critical discussions regarding masculinity in this novel, Peter Walsh and Septimus Warren Smith are mostly the characters of focus. Virginia Richter (2010) writes:

Figures like Septimus Warren Smith and Peter Walsh in Mrs. Dalloway display a sense of insecurity, a necessity to rethink their sense of identity in response to the changing times. These men function as seismographs registering the advent of modernity; despite their relative... and catastrophic failure to come to terms with the contradictory social roles with which they are confronted, they, rather than the inflexible defenders of power, patriarchy, and empire, represent a viable although precarious embodiment of modern masculinity. (p. 158)

Even though Peter and Septimus's masculinity brings a thought-provoking discussion to the novel, it is important to look at the major relationship in the narrative-Richard and Clarissa Dalloway. Richter's observations of Septimus and Peter also apply to Richard. Richard struggles to assimilate to social norms of masculinity and to meet Clarissa's expectations for him. His masculinity may not be as nuanced as Septimus and Peter, because he seems to fit the mold of a white, middle-class male more than they do; however, he faces similar struggles in his everyday interactions with Clarissa.

In Mrs. Dalloway, Woolf uses perceptions of other characters to describe the major characters while also using the inner dialogues of the characters to create her narrative. When discussing Richard, Woolf relies on Peter Walsh's perceptions of Richard and also Richard's perceptions of himself. Early in the novel, Peter Walsh tells the story of his first meeting with Richard. He says, "Clarissa called him 'Wickham'; that was the beginning of it all. Somebody had brought him over; and Clarissa got his name wrong. She introduced him to everybody as Wickham. At last he said 'My name is Dalloway'” (Mrs. Dalloway, p. 66). Clarissa's reference to Wickham starts a thought-provoking conversation because she equates Richard with a fictional character in Jane Austen's novel Pride and Prejudice. In Austen's work, Wickham illustrates the stereotype of a handsome male hero and is idealized by Lydia's character. Clarissa's misspeaking of Richard's name superimposes a stereotype of masculinity onto Richard before he engages in any dialogue. An argument can be made for Clarissa's immaturity at a young age and her admiration for Richard as part of her misspeaking; however, she holds closely to social constructs of masculinity through this encounter. Peter Walsh is not always seen as a reliable narrator, but his use of direct quotes from Clarissa and Richard convey the gendered messages in this dialogue.

Peter Walsh's narrative about Clarissa and Richard's relationship gives insight into Clarissa's expectations of Richard; however, Richard's narrative is most important in the discussion of his need to conform to social constructs of masculinity. When Richard's thoughts enter the novel, Woolf writes that "he never gave Clarissa presents except a bracelet two or three years ago, which had not been a success. She never wore it. It pained him to remember that she never wore it” (Mrs. Dalloway, p. 124). An argument can be made that Richard attempts to convey his sense of masculinity through buying Clarissa gifts. When she does not respond 
positively to these gifts, Richard feels emasculated. On the other hand, Richard's emotional attachment to these gifts raises the question, what event causes his emotional attachment to these gifts? Richard cannot reveal his emotional trauma regarding these gifts for fear that Clarissa would know about his feelings. In this case, Clarissa's negligence of Richard's emotions perpetuates the discourse of masculinity that her society inscribes for men.

In Judith Halberstam's (now identifies as Jack Halberstam) article, she uses psychoanalysis in her discussion of both male and female masculinity. She says, "Since psychoanalysis is a model of human sexuality that takes the male subject as normative and understands the body as the terrain for neurotic symptoms, then male failure will always be received as the presence of femininity" (Halberstam, p. 354). Richard exemplifies this perception of "male failure", because he feels that he does not please Clarissa with his gifts (Halberstam, p. 354). In response to this failure, Richard faces emotional trauma, but cannot reveal these feelings to the other characters because he would be perceived as effeminate. Halberstam's critique of gender plays out in Clarissa and Richard's narrative because they convey a dichotomy with gender roles. The reader does not see an interaction between Clarissa and Richard within this scene; however, Richard's reaction to Clarissa not wearing his bracelet conveys his pressure not to show emotion toward anyone, especially his wife.

Richard's thoughts continue this characteristic of not showing emotion as he buys Clarissa flowers. Woolf writes that:

Here [Richard] was walking across London to say to Clarissa in so many words that he loved her. Which one never says he thought. Partly one's lazy. Partly one's shy. And Clarissa-it was difficult to think of her; except in starts as at luncheon, when he saw her quite distinctly; their whole life. (Mrs. Dalloway, p. 125)

Richard struggles to say that he loves Clarissa and in the end never does. Again, his pressure to not express emotion comes from Clarissa's expectation of him to support her. Later in the scene, Woolf writes, "not that she was weak; but she wanted support” (Mrs. Dalloway, p. 127). In this scene, Richard and Clarissa also have no interaction. The reader relies completely on Richard's thoughts and his perceptions of Clarissa as a means of piecing together their relationship. Richard struggles to express his feelings for Clarissa and reveals that he does not fully understand her. He only sees her identity in relation to her luncheons and is unable to describe any of her other attributes.

When Richard gives Clarissa the flowers, she gladly accepts the gift, but she moves on to her party planning. Clarissa's thoughts race about the party: "Had Lady Bruton asked about her? Peter Walsh was back. Mrs. Marsham had written. Must she ask Ellie Henderson? That woman Kilman was upstairs” (Mrs. Dalloway, p. 128). Richard never tells Clarissa he loves her not only because he struggles to reveal his emotions, but also Clarissa's desire to be a good hostess causes her to ignore Richard's emotions. By ignoring Richard's love for her, Clarissa perpetuates the ideological discourse that men cannot display any emotion, especially to a woman. Clarissa's desire to conform to constructs of femininity causes her to assign masculine roles to Richard which makes her assume a role as part of the patriarchy. The novels ends with Clarissa's party-the culmination of the story. She and Richard's relationship continues to be explored through characters such as Lady Bruton and Sally Seton, but Clarissa and Richard have little interaction in this scene. Clarissa struggles to uphold social norms of femininity; however, she allows social expectations of masculinity to create a disconnection between Richard and her.

Lastly, Clarissa Dalloway exemplifies women's policing of masculinity during her party at the end of the 
novel. When Sally, Clarissa's friend, comes to the party, she questions Clarissa's relationship with Richard. Sally feels responsibility to Clarissa because "they had been friends, not acquaintances, friends" (Mrs. Dalloway, p. 206). Sally's reflections on the evolution of Clarissa's life illustrate her negative views of Richard: "to be quite frank then, how could Clarissa have done it?-married Richard Dalloway? A sportsman, a man who only cared for dogs. Literally, when he came into the room he smelt of the stables. And then all this?” (p. 206). Even though Sally's viewpoints of Richard should not be conflated with Clarissa's viewpoints of her husband, the reader sees how Richard has to obtain some level of masculinity in order to please not only his wife, but also her close friend.

Furthermore, the queerness of Clarissa and Sally's relationship illustrates Sally's need to in a sense protect Clarissa from Richard. In the beginning of the novel, Woolf presents Sally and Clarissa as close friends; however, their relationship can be interpreted as more than platonic. During Clarissa's reflections on her relationship with Sally, she parallels her feelings for Sally with Richard, which deserves a close reading in this analysis. Clarissa says:

But this question of love (she thought, putting her coat away), this falling in love with women. Take Sally Seton; her relation in the old days with Sally Seton. Had that not after all been love? ...The strange thing, on looking back, was the purity, the integrity, of her feeling for Sally. It was not like one's feeling for a man. It was completely disinterested, and besides, it had a quality, which could only exist between women just grown up. It was protective, on her side: ....which led to chivalry, this protective feeling which was more on her side than Sally's. (Mrs. Dalloway, pp. 34-36)

Clarissa also mentions that Sally "kissed her on the lips" which could imply a romantic attachment between the two women. Even though the queerness of the relationship is not the main focus of this article, Clarissa and Sally's early interactions inform their perceptions of Richard later in the novel. In this scene, Clarissa perceives herself as overprotective of Sally and does not see Sally reciprocating this same sense of protection for her. However, I argue that Sally's focus on Clarissa's relationship with Richard provides a counter narrative to Clarissa's perception of the relationship. In Woolf's book Moments of Being, she writes a series of essays about the writing process and her experience as a writer. In her essay "A Sketch of the Past", she discusses memory and its significance. When she reflects on her childhood memories, she says,

These then are some of my first memories. But of course as an account of my life they are misleading, because the things one does not remember are as important; perhaps they are important...Unfortunately, one only remembers what is exceptional. And there seems to be no reason why one thing is exceptional and another not. (Moments of Being, pp. 69-70)

Woolf's focus on memory and moments of "non being" in this chapter manifest in Clarissa's reflections on her relationship with Sally because she sees herself as the protective person in their relationship when Sally exemplifies protection over Clarissa by her dissatisfaction with Richard. Each character only expresses their own perspective and these perspectives do not always align with one another.

Going back to Sally's perception of Richard, both Sally and Clarissa feel that it is their role to protect one another as friends (and possible lovers). In order to maintain this sense of comradery, Sally feels that Richard does not uphold the standards of masculinity that Clarissa deserves. Furthermore, she gathers her information from Clarissa's interactions with Sally after she marries Richard:

All these years the Dalloways had never been once. Time after time they had asked them. Clarissa (for it was Clarissa of course) would not come. For...Clarissa was at heart a snob...And it was that that was between them, she was convinced. Clarissa thought she had married beneath her, her husband being—she was proud of it—a miner's son. (Mrs. Dalloway, p. 
In this scene, Sally conveys subtly why she feels so strongly about Clarissa and Richard's marriage. Sally believes that Clarissa feels that Richard is not good enough for her due to his socioeconomic status. Even though Richard maintains social constructs of masculinity through strenuous work, he does not have the family wealth that Clarissa has and wants to continue. Richard is able to uphold some standards of masculinity, but not others, which complicates the definition of masculinity in this novel. Butler (2004) says:

To assume that gender always and exclusively means the matrix of the "masculine' or feminine" is precisely to miss the critical point that the production of that coherent binary is contingent, that it comes at a cost, and that those permutations of gender which do not fit the binary are as much a part of gender as its most normative instance. (Undoing Gender, p. 42)

Butler argues that society views biological sex as a means of assigning gender to particular bodies, which presents problems for people who cannot uphold to the binary of masculine and feminine. Furthermore, Butler argues that this social system of assigning gender is inaccurate for all people not just people who do not identify within the gender binary. Richard Dalloway identities strongly as a man and we would today define him as upholding heternormative ideologies in his marriage and his daily life. However, his masculinity is contingent on the sex/gender system set up by society, which deems him as unable to perform correctly.

Furthermore, Sally gives more background information on Richard in her reflections, than Clarissa does throughout the novel. With this information in mind, I argue that Clarissa refuses to engage emotionally with Richard because he does not uphold completely social constructs of masculinity. Even though Clarissa does not seem to be economically suffering, she still yearns for more wealth so she can plan more parties for her friends. Even though Clarissa does not speak in this scene, Sally’s reflections not only convey Sally's opinions, but also Clarissa's embarrassment of her husband.

In the final few paragraphs of the novel, Richard and Elizabeth have a heartfelt interaction with each other. Woolf writes that "Richard was proud of his daughter. And he had not meant to tell her, but he could not help telling her. He had looked at her, he said, and he had wondered, Who is that lovely girl? And it was his daughter!” (Mrs. Dalloway, p. 212). Sally responds by saying "Richard has improved, you are right”. Lady Rosseter responds by saying "I shall go and talk to him. I shall say goodnight. What does the brain matter...compared with the heart?” (p. 212). Even though it seems that Richard wins the approval of Sally and Lady Rosseter, they continue to critique his masculinity even in their compliments. By implying that the heart matters more than the brain, they insinuate that Richard's mental capability is not up to a masculine standard. His heritage as a miner's son and his continued role in the working class does not require a high level of intelligence so he is deemed as a person without substance regardless if their opinion is accurate when applied more generally toward people. However, since he genuinely cares for his daughter, Richard exemplifies some level of worth to these women.

On the other hand, Richard conveys his struggle to show emotion his wife earlier in the novel and now in his compliments of his daughter. Going back to Halberstam's critique of masculine frailty, Richard continues the struggle to show emotion because he is socialized to believe that men cannot show any emotion toward anyone including their families. Furthermore, the female characters' perceptions of him as a failure as a man prove the discourse that he falls victim to in his society. By the end of the novel, we see that Richard's struggle to maintain some level of masculinity is far more than an internal struggle. After closely looking at Clarissa, 
Sally, and Lady Rosseter's perceptions of Richard's expressions of masculinity, his struggle comes from people in his inner circle (his wife and her friends) and his society at large. Moreover, his struggle to maintain his masculinity is policed by women in order to uphold the patriarchy that oppresses them.

\section{Mr. and Mrs. Ramsay - To a Definition of Masculinity}

In To the Lighthouse, Woolf introduces the Ramsay's - a couple that seems to hold to Victorian ideals of gender. However, this text clearly has feminist themes in the narrative. Most criticism focuses on Mrs. Ramsay's role as an oppressed member of the patriarchy and the story's centering on her character even after her death. Critics make valid points regarding her oppression in the patriarchy; however, they fail to look at Mr. Ramsay's role in the narrative. What do we know about Mr. Ramsay's masculinity? Does he struggle to define his masculinity? Who defines his masculinity? These questions need analysis in order to conduct a feminist study of To the Lighthouse because masculinity theory has many intersections with feminist theory. In her biography of Virginia Woolf, Hermione Lee discusses how Woolf wrote To the Lighthouse as a piece about her parents. Lee quotes Woolf's diary which says "I used to think of him \& mother daily, but writing the Lighthouse laid them in my mind” (qtd in Lee 80). Woolf's intended focus on her parents' relationship increases the importance a close reading of the relationship between the Ramsays to this argument. With this information in mind, we see that Woolf's intention was to depict the relations between a couple rather than just focusing on one person's narrative.

As in Mrs. Dalloway, Mrs. Ramsay also conducts dinner parties in order to achieve social status, but she does not find as much pleasure in the planning process as Clarissa. During the party, Mrs. Ramsay critiques Mr. Ramsay's expression of emotion. Mr. Ramsay does not like these dinner parties and openly expresses his feelings. In her mind, Mrs. Ramsay wrestles with her own frustration about her husband: "Why could he never conceal his feelings? ...wonder if Augustus Carmichael had noticed. Perhaps he had; perhaps he had not” (p. 55). In contrast to Richard, Mr. Ramsay expresses negative emotions which make his defiance important in looking at Woolf's depictions of masculinity. Mr. Ramsay's expression of frustration shows emotion that is not acceptable for men. Even though he does not show positive feelings toward anyone in this scene, he does manifest some type of emotion which goes against hegemonic standards of masculinity. Mrs. Ramsay wants her husband to remain silent and also fears how other men will perceive him. Mrs. Ramsay does not want her husband to show any kind of emotion at her dinner party. Furthermore, she wants him to emulate the masculinity that Carmichael manifests. "Whether people laughed at him or were angry with him he was the same. He did not like her, she knew that; but partly for that very reason she respected him” (p. 55). Mrs. Ramsay has "respect" because he does not react to situations in different ways, which makes Carmichael more logical in her mind (p. 55). His ability to not act out maintains a sense of masculinity, which is a common stereotype for men. The opposite of remaining calm would be hysterical which is a stereotype of women, especially in this era. Since Mr. Ramsay appears to be exemplifying emotion, Mrs. Ramsay reacts negatively to this expression and compares him to Carmichael. Even though Mrs. Ramsay does not explicitly discuss her husband or Carmichael in relation to their masculinity; however, we see how she makes these connections through her stream of consciousness.

By looking at Mrs. Ramsay's policing of her husband's masculinity, one must engage with how masculinity is perceived within social settings. In feminist critic Nancy Chodorow's article, she focuses on men's violence toward women, but she analyzes men's sense of masculinity. She says that men's "sense of 
masculinity is also generally more fragile than women's sense of femininity” (p. 253). In most cases, I agree with her conclusion; however, Mrs. Ramsay’s rhetoric conveys the opposite idea. Mrs. Ramsay manifests more concern about other men's perceptions of her husband's masculinity than he does. He embraces his feelings, but Mrs. Ramsay does not have the same feelings. In this scene, Mrs. Ramsay becomes complicit in the patriarchy because she assigns assumed gender roles to her husband even though she herself faces oppression within this same system. In order to maintain the patriarchy of Mrs. Ramsay’s society, the system relies on her cooperation.

Mrs. Ramsay continues this critique of her husband's masculinity when she watches him read Sir Walter Scott. Woolf writes:

He was reading something that moved him very much. He was half smiling and then she knew that he was controlling his emotion....And if he came to the conclusion "That's true" what Charles Tansley said, he would accept it about Scott...But not about himself. He was always uneasy about himself. That troubled her. He would always be worrying about his own books - will they be read, are they good, why aren’t they better, what do people think of me? (To the Lighthouse, p. 67)

Mrs. Ramsay again suggests that she takes issue with Mr. Ramsay’s sense of self and his need to express emotion. Karen Kaivola points out that "Mrs. Ramsay's self effacement when confronted with her husband's imperious demand for female sympathy is exasperating: she gives willingly, but not without personal cost” (p. 204). In Mrs. Ramsay's mind, Mr. Ramsay should convey some level of confidence as a man and she critiques his failure to do so. Even though she tries to give her husband the attention she feels he desires, she still emasculates him by giving into patriarchal norms for masculinity. Kaviola argues that even though there are these patriarchal gender norms in the Ramsay's relationship that they still convey "an understanding rooted in the ethics of love” (p. 204). This argument is not the main focus of this paper; however, I argue that whether or not the Ramsay's have a relationship that centers on love, their need to conform to hegemonic gender norms cannot be ignored. Mrs. Ramsay subtly conveys her expectations of her husband, which in turn makes her part of the patriarchy that oppresses her. By prescribing masculine norms to her husband, Mrs. Ramsay claims her place within the patriarchy.

\section{Conclusion}

Woolf intends to create positive female characters in her fiction and wishes to critique gender norms in her pieces. However, when one questions gender roles, an analysis of masculinity must take place in order to look at Woolf's critiques more in-depth. The dominant structure must be taken into account in order to have a conversation about the oppressed group. Even though theorists such as Butler and Chodorow are associated with discussing the oppression of women within the patriarchy, their work is also necessary in critiquing masculinity and its structure in the patriarchy. A close reading of Woolf's depictions of masculinities gives a more nuanced approach to reading text under a feminist lens because masculinity theory intersects with feminist theory. According to Judith Newton, "masculinity studies...make a profound intervention in the tendency of feminist theory to celebrate the diversity and fluidity of femininities and women while over unifying and sometimes demonizing the categories of masculinity and men” (p. 181). Newton's definition of masculinity studies conveys the need to bring these ideas into conversation with feminist theory and into feminist criticism of literature.

Feminist theory needs to focus on positive female characters; however, negative female characters also 
need exploration which is one of the goals of this paper. Jacob Flanders, Richard Dalloway, and Mr. Ramsay all illustrate men who are products of their societies, which I do not negate in this project. In their own ways, these men perpetuate the discourse of femininity. On the other hand, these men must adhere to the masculine expectations of their significant others. Clara Durrant, Clarissa Dalloway, and Mrs. Ramsay illustrate women who suffer from the perils of the patriarchy, but they also become perpetrators within the patriarchy in their expectations of their husbands. These women continue to perpetuate the ideological discourse of masculinity and prescribe gender norms for the men. Woolf not only proves that men's masculinity needs to be brought into conversations about gender, but also she illustrates how women contribute to these flawed senses of masculinity.

\section{References}

Bell, V. M. (2006). Misreading “Mrs. Dalloway”. The Sewanee Review, 114(1), 93-111. JSTOR. Web. 25 Apr. 2014.

Butler, J. (2004). Undoing gender (Vol. 1). New York: Routledge.

Chodorow, N. J. (2002). The enemy outside: Thoughts on the psychodynamics of extreme violence with special attention to men and masculinity. In J. K. Gardiner (Ed.), Masculinity studies and feminist theory: New directions (Vol. 1, pp. 235-261). New York: Columbia University Press.

Halberstam, J. (2002). The good, the bad and the ugly: Men, women, and masculinity. In J. K. Gardiner (Ed.), Masculinity studies and feminist theory: New directions (Vol. 1, pp. 344-367). New York: Columbia University Press.

Hollander, R. (2007). Novel ethics: Alterity and form in Jacob's Room. Twentieth Century Literature, 53(1), 40-66. Literature Resource Center. Web. 25 Apr. 2014.

Kaivola, K. (2013). Revisiting the Ramsays: Love, alterity, and the ethical experience of the impossible in Virginia Woolf's To the Lighthouse. Lit: Lit Interpretation Theory, 24(3), 202-225. Taylor and Francis Online. Web. 3 Aug. 2015.

Lee, H. (1999). Virginia Woolf. (2nd ed., Vol. 1). New York: Vintage Books.

Newton, J. (2002). Masculinity studies: The longed for profeminist movement for academic men. In J. K. Gardiner (Ed.), Masculinity studies and feminist theory: New directions (Vol. 1, pp. 176-194). New York: Columbia University Press.

Richter, V. (2010). Women constructing men: Female novelists and their male characters, 1750-2000. In Sarah S. G. Frantz and K. R. Lexington (Eds.), The differential construction of masculinity in the writings of Virginia Woolf (pp. 155-170). Rowman and Littlefield.

Woolf, V. (1953). Mrs. Dalloway (1925, 2nd ed. Vol. 1). Orlando: Harcourt, Brace, \& World Inc.

Woolf, V. (1985). Moments of Being. Virginia Woolf Moments of Being (2nd ed.). J. Schulkind (Ed.). San Diego: Harvest/HBJ.

Woolf, V. (2008). Jacob’s room (1922, 3rd ed., Vol. 1). Orlando: Houghton Mifflin Harcourt Publishing Company.

Woolf, V. (2010). To the lighthouse (1927, Vol. 1). London: Cathedral Classics Aziloth Books. 